\title{
Religious statecraft: Narratives of persecution and diplomacy in the case of Byzantine, Aksum and Himyar
}

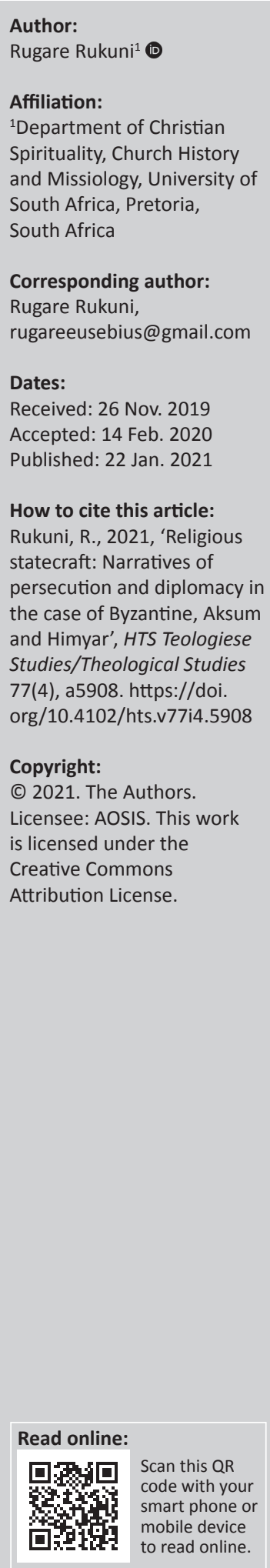

When reviewed against the background of Byzantine diplomatic correspondence, Aksum's religious policy on the Arabian Peninsula is perceivable within a Constantinian religio-political matrix. Imperial letters from Byzantine to Aksum and Persia denote the Byzantine role of arbiter of early Christianity. Byzantine Rome's role in Christianity when reviewed from diplomatic correspondence with allies and antagonists recounts narratives of orthodoxy and persecution. Parallel review of letters from Constantine and Constantius decodes the Christian kingdom of Aksum as a participant of 4th-century CE Constantinian dynamics. This review was enabled through document analysis.

Keywords: Christian history; Aksum; Byzantine; Persia; Himyar; Constantine; Kaleb; persecution; diplomacy; war.

\section{Introduction}

There is a case for the review of Aezana's conversion as a diplomatic move to embrace the political and economic consequences of an alliance with Rome. This theory entails an essentially political definition of the Christianisation of Ethiopia. The existence of mutual alliances between Rome and Aksum cannot be deemed to have been preceding and prevailing over the JudaicSyriac cultural-religious complex to which can be dually traced the Christianisation of Aksum (Ullendorff 1956). In perspective of clerical-imperial dynamics as exhibited during the reign of Constantine and the resultant politico-ecclesiastical continuum he ignited, correspondence between Byzantine and Aksum helps decode the terrain of 4th-century CE Christian orthodoxypolitical dynamics. The letter of Constantius sent to Ezana and that of Constantine to Shapur II enhance the preceding view. This significantly integrates the phenomenon of Aksumite Christianity into the continuum created by the polities of Nicene orthodoxy and the consequential geopolitical implications.

\section{Methodology}

Document analysis was the main method implemented, which entailed the review and evaluation of primary and secondary sources (cf. Bowen 2009:27; Ritchie \& Lewis 2003). In association with the nature of the narrative that implies social dynamics, there was reference to cultural historiography (Danto 2008:17). Dually, the complex nature of the religio-political synergies involved in the narrative implied the application of a perceptive lens that assigns significance to enculturation and self-definition (Rukuni 2018:156). The engagement with antique correspondence between monarchs implied the archaeology of religion (Insoll 2004:59, 61; Yamauchi 1972:26).

\section{Letter of Constantius to the Ethiopians against Frumentius: Constantius Victor Maximus Augustus, to Azanes and Sazanes}

Wherefore considering that you are deserving of the same provident care as the Romans, and desiring to show equal regard for your welfare, we command that the same doctrine be professed in your Churches as in theirs. May God continually preserve you, most honoured brethren. (Athanasius Apologia Ad Constantium 31; ed. Schaff 1892:497-498) (Pankhurst 1956:58-59)

The letter is dated c356 CE, and corresponding to its timing, it arguably reflects the religio-political dynamics consequent of 4 th century Christendom. The preceding observation is affirmed by the active voice used by the emperor in an attempt to re-align episcopal hierarchies. In addition, the prominence of Aksum resurges in the manner in which it was entangled in Byzantine ecclesiastical polities (Sellassie 1972:99). 
The letter has received attention from a wide range of scholarship, and this arguably derives from the manner in which the letter fits the category of antiquities, theology, political studies and history. Hendrickx reviewed the letter within a connotation of an Afro-Byzantine context, and placed a group of authors on an index (Hendrickx 2017:3). This index ranges in perception with the ultimate portrayal of an obstinate Ethiopia abdicating itself from Roman dominance (Papadopoulos 1935-1985:180-204).

\section{An economic-political client Christianity}

Another viewpoint is to aggregate the Christianity of Aksum as a phenomenon of political alliance and Roman client influence (Mathew 1963:99). The preceding assertion is based upon the documented role of Aksum in maritime Graeco-Roman trade, against the reality of the Persian land route, correspondingly the geopolitical significance of its geographical location to Roman imperial influence on the Arabian Peninsula. Aksumite Christianity is relatively deduced as a function of the Roman-Aksumites, correspondent to the preceding assertions. This view whilst acknowledging the intrinsic significance of Ethiopia within the Mediterranean, Red Sea and Indian Ocean world diminishes the sophistication of religiocultural dynamics.

Deducing Aksumite Christianity, as essentially elementary to political attachment to Rome, principally ignores the intricate background of Ethiopian Christianity. Kobishchanov hints as per the statement of Athanasius that the letter was part of a continuum of letters sent by Constantius to the Ethiopian monarchs; in addition, in his attempt to control Christendom, the Byzantine emperor over-reached his boundaries in disregarding the assertive sovereignty of Aksum (Kobishchanov 1979:99-200). The narrative that establishes native resistance against the imperial establishment resonates with the fluid power dynamics on the continent of Africa consequent of the decline of western Rome and rise of the Vandals (cf. Whelan 2018). Sellassie observes the existence of the politico-religious matrix as evidenced by how the negus Ezana was arguably an essential authority in ecclesiastical affairs; this was based on the letter that indicates how the Byzantine emperor expected the monarch to intervene (Sellassie 1971:64-65; 1966:6-7).

Constantius decreed limitations to the durations persons under imperial service were allowed when in religiously divergent Aksum or Alexandria (Munro-Hay 1991:4-5). When viewed in perspective of the letter, this would entail the emperor's entanglement within the ecclesiastical polities. After all, this can be viewed as an effort to maintain the Arians-Nicene caste. Against the reality of clerical and imperial polities, the emperor's actions are an attempt to determine orthodoxy within the extended realm of Christendom (Letsios 1988:165-166). Constantius can be perceived as pursuing a Constantinian role of maintaining church unity; however, this came against the reality of an aggregate majority of a Nicene orthodox group (cf. Behr 2004). In this particular scenario, the emperor had just chosen a side and was enforcing this as the acceptable position (Hendrickx 2017:6-8; Letsios 1988:165-169).

Perceivably, this incites an introspection into modern Constitutional law and foreign relations in tangent to religious dynamics. This adds to the politico-religious momentum characteristic of the Constantinian ecclesiasticalimperial establishment. The actions of the emperor Constantine re-defined the interaction between politics and Christianity, and reviews on this subject can inform the development of a balanced legislative template. Barnes, the notable scholar on Constantinian subjects did not substantially address the issue of the letter and the relation of Aksum to Nicene orthodoxy (Barnes 1993:119-120; Hendrickx 2017:6). However, Barnes emphasised the manner in which Constantius endeavoured to posture as Constantine in furthering the interests of Christendom beyond the imperial borders. This can also be aggregated as having been an imperial power play to widen the influence of Rome. The aforementioned point relating to role of the emperor and the posturing by Constantius is arguably an established notion amongst a variety of authors; however, assigning the same political significance to the conversion of Ezana may be perceivably misplaced.

\section{Self-defining Christianity and divergence from unilateral orthodoxy}

The view that would categorise Ezana's decision within its entirety as a political decision ignores the reality and sophistication of the enculturation or contextualisation of religion and self-definition (cf. Lieu 2006:214; Roldanus 2006:6). There was an ethnic-cultural element to the Christianisation of Ethiopia and the preceding environment influenced by Judaism adds to the complexity of this Christian cultural-political matrix. As explained earlier, the actions of the Negus had derivative and implied relations to the national environment in Aksum and the prevailing traditions. Correspondingly, Haas made a parallel analysis of the Christianisation of two monarchs within their diverse civilisations in tangent with Constantine (Haas 2008:101-126).

The significance from the observations made by Haas lies in how he balances the cultural and political side of the narrative that explains the conversion of the Aksumite and Iberian monarch. The first notable fact in Haas is the independent review of Aksumite Christianity within its immediate political, social and cultural context. The preceding implies a comprehension of the intrinsic orthodoxy within Aksum.

Haas emphasises the danger in generalising the form and shade of Christianity in different localities (Haas 2008). Arguably, Haas makes room for the existence of national orthodoxies an aggregately recurrent feature within Christendom, even in the 2 nd -7 th centuries CE. Against the 
background of Donatists and Nicene-Homoian parties in the Vandal era, the correlation between divergencies in orthodoxy and politics can be established (Roldanus 2006:174-175; Whelan 2018:15). In addition, when considerate of the fact that there are realities in orthodoxy that are consequent of cultural-ethnic dynamics, the Christianisation of a nation cannot be deduced as a resultant of politics only. Therefore, Haas emphasised that for the emperor Ezana, the acceptance of Christianity was not a political decision but rather one cultural (Haas 2008:102-116).

\section{Religious diplomacy}

The correspondent diplomatic approach by the Byzantine emperor in his international geopolitical policy is what makes up for the political aspect of the matter. The Byzantine empire was the one in pursuit of regional economic-political counter-measures against the Persian empire, thereby making Aksum an important client or proxy within the Arabian Peninsula. Whilst it could not be controlled completely, shared economic-political interest between the two Christian nations could guarantee a steady alliance. The independence of Aksum is without doubt, as evident in the compromise relationship between the emperor and the Negus. This view decodes the letter as a diplomatic endeavour by the emperor Constantius to reach out to a significant power in the Southern part of Africa Proconsularis, adjacent to Himyar and along the Berenice (Egypt) to Muziris (Indian) maritime trade route. If anything, the letter affirms the geopolitical significance of Ethiopia and not its perceived subservient Christianisation.

Hendrickx, the author of various titles on Aksumite Byzantine relations, further analysed the letter. He noted how the letter was primarily religious and not political or economic; however, given the political nature of orthodoxy in 4th century $\mathrm{CE}$, the letter explicitly transcends ecclesiastical agendas as it reflects on imperial policy (Hendrickx 2017:8). According to Hendrickx, the format of the letter is what is known as a Keleusis. This is reference to imperial communication to inferior regents (Karayannopoulos 1972:191, 193, 200). The format is assumptive of the authority of the Byzantine emperor who is giving directives to the Aksumite monarchs; in addition, coupled with the mentioned directives are warnings akin to divine threats. The concluding hint towards diplomacy was intrinsically conditional upon conformity. Late RomanByzantine imperial correspondence was formatted as letters that can be categorised into sacrae, graphai and grammat (Classen 1977:48, 57, 223-225; Hendrickx 2012b:21-33).

Hendrickx asserts that Constantius' letter is a sacra as correspondent to the use of the same category (sacra) latter by Justinian in communication with Himyarite and Aksumite monarchs, Arethas and Kaleb, respectively, through Julianus who was dispatched by the emperor

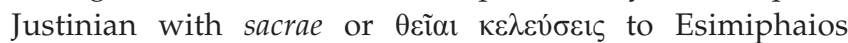
and Kaleb as a Christian call to arms against Persia
(Procopius I.10.9, ed. \& transl. Dewing 1914-1928; Hendrickx 2017:9; Vasiliev 1950:395-398), thereby classifying these respective letters as of a category bespeaking religious matters.

The format of the letter as a Keleusis has implications on the relationship between the correspondent nations, the direct deduction being the inferiority of the other nations without the empire. There is an absence of three elements of medieval diplomatic correspondence, as noted by Hendrickx, there is no intitulatio [details regarding the issuer of the letter], salutatio [formal Roman greeting] as per chancellery tradition and an omission of the datatio [year and day assigned to the letter] (Hendrickx 1984:69-74; Theophanes, Turtledove 1982:244-245).

It has been noted that the assumed superiority of the Byzantine emperor was consequent of the perception of Axum as belonging to the Byzantine oecumene, consequent of the orthodox imperial of the 4th century CE. However, the contract between the Byzantines and the Aksumites became more cordial with the dwindling of Roman dominance against the Persian threat (Christides 1972:115-116; Hendrickx 2017:10; 2012: 21-33, 95-114).

\section{Aksum amidst religious world war}

Another letter that enhances the comprehension of the 4 th century CE is the correspondence between Constantine and the Persians and how this re-images the conflict as one that was intrinsically religious. The agenda of the war as deliverance of persecuted Christians by a Zoroastrian monarch raises several questions for enquiry. The first is how the Persian war would fit into Constantine's neo-religious imperial policy as a defender of Christianity; this had been evidenced in his war against Licinius, a former ally-turned enemy, by persecuting Christianity (VC II.15-19, Cameron \& Hall 1999:235-237). Secondly, Constantine had defined the role of an imperial protector of Christianity liberae ecclesiae [liberator of the Church], thereby distinguishing himself from his predecessors 'tyrants' who persecuted Christianity. Thirdly, the Persian war found a momentum that perceivably was parallel to the orthodoxy dynamics of Nicaea and Chalcedon, and hence its inheritance by Constantine's successors. By extension, a dominant geopolitical power was emerging in the southern part of Africa and it was Christian. The role of Aksum as a defender of Himyarite Christians and Roman ally in neutralising Persian influence on the Arabian Peninsula thereby derives from this Persian war in a sense.

\section{Letter of Constantine to the Persian emperor Shapur (excerpts)}

Guarding the divine faith, I participate in the light of truth. By these things therefore ... I acknowledge the most holy religion. Having the power of this God as ally, ... I have raised up the whole world step by step with sure hopes of salvation, so that 
all those things, which under the slavery of such great tyrants yielded to daily disasters and had come near to vanishing, have enjoyed the general restoration of right ... The God I represent is the one whose sign my army, dedicated to God, carries on its shoulders, and to whatever task the Word of Justice summons it goes directly ... So because he also values highly righteous empire, he strengthens it with his own resources ... (VC 4.8-14, Cameron \& Hall 1999:156-158)

When considered against the background of Eusebius' Vita Constantini [Life of Constantine]. The generosity and magnanimity of Constantine is correspondent to the themes as liberae Urbis [liberator of the city], and the emperor had re-defined the imperium from as distinct from the age of tyrants such as Maxentius (Corcoran 2006:49; VC IV.1, ed. Schaff 1885b:818).

The portrayal by Eusebius is one that emphasises how Constantine was a benefactor in both secular and Christian circles (VC IV.2-3, ed. Schaff 1885b:755-756). Adversely, however, the beneficence of the emperor did not stretch across to the pagans, such as the Goths, as these were conquered through brute force. The letter exudes the impression that the monarch or emperor was a divinely appointed ruler recognised and dominant over much of the then world. This is observably not new as it was the practice of Persians as evident in Achaemenid relief sculptures (Lincoln 2008:221-41). This notion as practised and held by great Persian emperors such as Darius implied the supreme reign of the Persian monarch over other peoples, who though whilst retaining their distinct ethnicity, political and economic subservience was required (Lincoln 2007:23).

\section{The letter within Constantinian aura}

This letter formed the continuum that was latter exhibited in the imperial policy of Constantius, correspondingly international imperial policy would embroil the emperor within Christendom's ecclesiastical polities (Millar 1982:2). This is given the element within this diplomatic correspondence that relates to the protection of Christians within Persia. The principle of the protection of persecuted Christians would find resonance with the Aksumite Negus. The sole reign of Constantine in the $320 \mathrm{CE}$ and that of Shapur II (c309-379) lie within the era of Christian dynamics in Ethiopia (Smith 2016:20). The advent of the first Syrian Christians and the Christianisation of the Negus took place within the 4 th century $\mathrm{CE}$, thereby making the diplomatic correspondence a reference point to monarchs within this era.

According to Smith (2016:21), to rightfully interpret the letter against its appropriate background, the date is paramount. That is arguable given the significant development in ecclesiastical and imperial polities in 4th century CE. Perceivably, this letter attempts a rewrite of Roman history in correspondence with the Nova Roma [New Rome] themes that characterised the reign of Constantine the Christian emperor. The Nova Roma
[New Rome] themes identifiably relate to the deductions regarding the perception of Constantine in Eusebius as Liberator Urbis and Liberator Ecclesiae, that is, liberator of the city and liberator of the church, respectively (cf. Leithart 2010). Therefore, the theme of Constantine as a benefactor defines the letter intrinsically, whereas Constantine is portrayed as the magnanimous regent; dually, he also postures as the protector of Christianity. By mentioning that there were Roman persecutors of Christianity in preceding centuries and that the same met their downfall at the hands of Shapur's predecessor has derivative implications. Firstly, whilst this would politically seem to exalt the might of Persia as having been significant to the effect of defeating the glory of Rome, there appears to be a re-emphasis upon the conquering sign of the cross theme (Van Dam 2011:66). Explicitly, the fact that Roman persecutors of Christianity were conquered by the Persians, whilst Constantine had achieved notable eminence correspondent to the visits by innumerable emissaries of which the Persians were a part, implies that the greatness achieved by Constantine was through the en hoc signo vincis [by this sign conquer]. Therefore, the Christian God was indirectly responsible for the victory of the Persians over the Roman Emperor Valerian, and directly involved in Constantine's wars that ultimately saw his assumption to sole ruler after defeating tyrants and persecutors Maxentius and Licinius, respectively (Potter 2013:145).

\section{Premediaeval Crusades: Christian persecution and imperial interests}

This letter can be deduced as the extended cause for the persecution of Christians in Sassanid Persia (Smith 2016:21). In addition, the letter had been documented in Latin but a Greek transcript was given to the Persian ambassador, as it was known amongst the literati of the Persian empire that this is evidenced by trilingual inscriptions datable to the Sasanian era (VC IV.8,32, ed. Schaff 1885b:820-821, 830).

The letter incited the persecution of Persian Christians as it emphasised the role of Rome even within Persia as a protector of Christianity (Blockley 1992:11). The mutual prominence of Rome and Persia entailed that there would always be a shaky balance of power on the Eastern front. The clash between Roman and Persian interest was not only political but also economic as evident in the two routes: the maritime and land route (Warmington 1974:61). However, under the guise of benevolence for the Christian religion, the letter is an explicit foreign policy stunt (Barnes 1985:131). This thereby implies aggregate Roman intervention within Persian affairs. The actions of Constantine when reviewed against his rise to the sole ruler within Rome paint a repetitive religious-politicalmartial policy.

After defeating Maxentius, Constantine conjointly issued a decree of toleration for all religions inclusive of Christianity with Licinius (VC I.41.3, Cameron \& Hall 1999:220). It appears that there was a brewing political rivalry that was 
undermining the new-found alliance and peace. This is evidenced by the failed conspiracy orchestrated by the pagan senators in Constantine's court and his ally-turned-rival Licinius. Arguably, the persecution of Christianity by Licinius in Edessa after the edict of toleration was an excuse needed by Constantine to go to war with his eastern counterpart (Cureton 1864:72-85). This background perceivably explains the letter and the war with the Persians, and the letter can be decoded as direct provocation, which rings of an underlying tone 'protect the interests of Christianity or become God's enemy', whereas Constantine was an ally of God (Brock 1982:2). Extendedly, this enables a revision of the Red Sea wars between Aksum and Himyar, more especially given the common background of persecution of Najran Christians and the intervention of the Negus as a protector of Christianity in that region (Book of the Himyarites, ed. Moberg 1924).

Whilst it can be said that Eusebian religio-political thought shaped the 4th century CE Christian perception in both Christian and pagan circles principally, it also has to be noted that the extent of influence of the cleric's writings transcended the geography of the Roman empire and rather followed the spread of Christianity itself (Brock 1992:212; Debie 2006:18-26). Eusebius' Martyrs of Palestine had a Syriac version, preserved manuscripts that are datable to 411 CE are evidence of this fact (Wright \& Mclean 1898: 631-33). Within Eusebius, there is an extricable prevailing tone of piety and power, that is, how the church and state share a common interest (cf. Ferguson 2005). This would ultimately entail the perception of Christianity within Persia as an extension of the Roman-Byzantine empire. The years of the persecutors in the Roman empire had all along implied Christianity as an enemy to the pax deorum [peace of the gods] and, therefore, a liability to the empire. On the opposite, what destabilised Rome was an ally to Persia. The preceding notion perceivably explains the political reason why the Parthians had always been known to be tolerant of Christianity (Mingana 1907:106, 109).

The conversion of Tiridates an Armenian king and its corresponding influence on the subjects who became Christian, possibly acted as a wake-up call to the Persian emperor as this implied the existence of client religion of Rome in its proxy allies (Soz. HE II.8, ed. Schaff 1885c:375). This would be decoded as a political threat upon the Persian empire (Becker 2014:7-25).

In this line of thought, deducing Christianity as the threat to Persian autonomy and interests, in perspective of the adoption of Christianity by a new sole Roman emperor, further establishes the connection between the persecution of Christians and geopolitical policy of the two empires of Rome and Persia. Persia had not been exempt from the dynamics of migration and economics that spread Christianity along the Red Sea route. Whilst Persia had retained control over the land route, the reality of travelling Christian merchants as well as migrating persecuted Christians before Constantine implied a significant Christian population (Warmington 1974). Therefore, persecution of
Christianity would be extensive as correspondent to the presence of Christianity within the Persian empire. The above observations regarding how Christianity would be identified with Roman interests show how Constantine had introduced a symbiotic attachment between Romanitas and Christianitas (cf. Smith 2016:34).

\section{Rome as protector of Christianity: Template for Aksum}

The actions of Constantine in relation to the letter and the offense against the Persians enhance the comprehension regarding the claim by Constantine as the Bishop 'over those outside', as this has to be positioned amidst the realities of the imperial ecclesiastic dynamics of 4 th century CE (Cameron \& Hall 1999:320; VC IV.13, ed. Schaff 1885b:822). This redefines and reiterates the enquiry regarding the position of the emperor within the Church, a dynamic that would directly affect Aksumite Christianity. As correspondent with the actions of the emperor pre-Nicaea and post-Nicaea, the actions of the emperor had been for the promotion of Christian orthodoxy throughout all Christendom. This could also have implied that the emperor was the universal bishop responsible for Christians' interests without the jurisdiction of the empire (Cameron \& Hall 1999:320; VC IV.24, ed. Schaff 1885b:826; Seston 1947:127-131). This possibly was the emergence of Caesaropapism, the Byzantine development of the Byzantine imperial ecclesiastical establishment (Rapp 1998:685).

Constantine's reference to Valerian reflects the dynamic shift in imperial tradition to exalt Christianity and make it the Roman identity. The demise of Valerian at the hands of the Persians was celebrated amongst them as evident on the relief sculptures at Naqsh-e-Rostam (Herrmann 2000:35-45; Herrmann, Mackenzie \& Howell 1989:13).

This was specifically mentioned within ecclesiastical histories (Soz. HE II.15.4, ed. Schaff 1885c:381). Constantine in this aspect welcomes the demise of the glory of Rome as personified in its emperor Valerian because he had brought upon Rome the indelible stain that came from his persecution of Roman citizens who, in turn, found refuge amongst Barbarians. In addition, Constantine deconstructed the pagan psyche by taunting the abominable blood and foul hateful odours (Orosius, Ad. Paganos VII.22, ed. Fear 2010:393-394).

The emperor would rather find common cause with the Persian monarch who correspondent to his piety would protect Christians unlike former Roman tyrants. This new sentiment resounded in Christian tradition (Soz. HE II.15.4, ed. Schaff 1885c:381; Chronicle of Seert, Scher 1908). The victorious Shapur I is connected with the demise of the pagan Valerian and mutually the prosperity of Antiochian Christians who had migrated into Persia. The capacity enabled by the new-found freedom in Persia where they did not face the implications of being a religio illicita [illegal religion] saw the establishment of monasteries and churches (Chronicle of Seert, Scher 1908:220-221). 
The emphasis upon the degradation met by Valerian at the hands of Shapur I by both the imperial and ecclesiastical establishment as resonant within Eusebius, Lanctantius' Death of the Persecutors redefines Roman history as Christian (Zos. HN I.36.2, Ridley 1982:11-12; Lactant. DMP V.5, ed. Schaff 1885a:462). Lactantius paints a picture that parallels that of Constantine (Drake 2000:292; Frendo 2001:65; Oration Cons. Or. XXIV.1-3, ed. Schaff 1885c:878).

The letter generally can be deduced as a preceding diplomatic correspondence between the two empires that were about to engage in war based on the persecution of Christianity within Persia. The aftermath of the war stretched into the succeeding Constantine dynasty. In addition, this war embroiled a new player in ecclesiastical-state dynamics of the Kingdom of Aksum. The fact that bishops were part of the entourage and stratagem of Constantine's offense brings to view the 4th century establishment of Constantine as imperial Christianity. Bishops were engaged in and formed part of the parade. Constantine as per the mosaic impressionism by Eusebius also had a mobile church that would be carried to the front as his practice in earlier battles against antagonistic pagans (Hollerich 1989:80-85; HE IX.9.3-8, ed. Schaff 1885b:582-583; VC II.12.1, ed. Schaff 1885b:759-760; Soc. HE I.18.12, ed. Schaff 1885c:48-49; Soz. HE I.8.10, ed. Schaff 1885c:348).

There is another view to Constantine's war, in manner similar to how Zosimus laments detrimental secular-political reasons for Constantine's neo-religious policy (Zos. HN II.38, Ridley 1982:40-41). Ammianus implies that Constantine wanted the war, relying upon a respective tale of confrontation between Constantine and the Persian emperor based on a hoard of jewels sent from the Indian regent (Amm. Marc. XXV.4.23, Warmington 1981:464-468). Despite this, there is established reason for deducing the war as a religious crusade that fitted into the continuum of Constantine's developing relation to Christendom (Barnes 1985:132, 136).

Although the idea from Marcellinus implies the existence of hostilities between the two empires that were further heightened by either regents' expansive ambition, tensions regarding border disputes, for example, would not be unusual in such an environment. In this hostility, persecution of Christians who were now patronised in the emerging Roman state became a further source of agitation (Brock 2009:309-379). A worthy example would be the clashes in Roman Mesopotamia (c337-350 CE), where the stronghold of Nisibis which was Roman had been attacked by Persia; however, despite the continued attempts, the Romans did not cede (Dodgeon \& Lieu 1991:159). In addition, Nisibis was predominantly Christian and hence here was a region within proximity to the turf of Persia, yet completely under Roman control (Smith 2016:66, 67).

Sozomen painted a picture that implied a necessitated intervention by the force claiming to be a defender of Christendom (Soz. HE II.14.5, ed. Schaff 1885c:380). Shapur II was said to have martyred 16000 Christians by burying them en masse such that recognition of individual identities would be impossible. Sozomen's account is derived, however, from Simeon's acts and accounts from Beth Huzaye martyrs (HE II.9-12, ed. Schaff 1885c:375-379; Smith 2014:24-29).

Aggregately, Sozomen and Theodoret paint a picture correspondent to a patronised clergy of the 4th-5th century where the primary focus was the imperial intent as patron of Christianity. Notably, the History of Blessed Simeon bar S. abba'e, as the main source of the martyrdoms, is from the late 5th century CE, and ecclesiastical histories such as those of Sozomen and Theodoret were derived from it. Given the relationship of Aksumite Christianity with Byzantine and Eastern Christianity, arguably, it can be inferred that there would be parallels between martyrdom accounts for Christians in Najran-Zaphar in the region of Himyar and the respective Persian source. The manner in which the martyrdom accounts would reflect on the impact of the persecutions on Christianity and dually upon state relations enhances the perception of how Constantinian establishment of ecclesiastical-imperial statecraft affected Aksum.

The death of Constantine and the ensuing power vacuum implied a tip over in the war and the prolongation and expansion of the scope of conflict. It seems the demise of Constantine emboldened the Persian monarch who correspondingly raided Roman territory systematically (Burgess 2008:5-51).

The place of Nisibis within the Roman-Persian conflict is insightful for both the essential nature of Constantine's clash with Shapur II and extendedly for Aksumite-Himyarite relations (Amm. Marc. XVIII.6.8, XX.7.1, XXV.7.11, XXV.8.17, transl. Yonge 1911:173, 226, 394, 398).

This notion is substantiated by the dual significance of the city to the imperial and ecclesiastic establishment. Firstly, the city was important to the Persian land trade route, which was the point of access in trade between the Romans and Persians (Elton 1996:88; Amm. Marc. XXIV.9.1-2, Matthews 1986:549-569).

The critical nature of the city to both empires was intrinsic, whilst it was part of the gateway to the East for RomeByzantine trade and military endeavours; virtually, it was a consistent reminder of a looming Roman threat to Persian geopolitical policy. In perspective of Constantine's rise to the sole emperorship and his role within Christendom, Nisibis was an indicator of how close Persia was to facing Roman subjugation.

In terms of the above discussion, the history of the city in perspective of the shift in Roman imperial dynamics and fortune of Christianity had a bearing on the primacy of the city and its implicative narrative. During the Roman persecutions of Galerius, Valerian, as discussed earlier, Roman Christians would migrate to Persian or eastern regions. The fact that the city had been refuge to Christians 
whilst it was under Persian rule and that it came under Roman domination in tangent with the Christianisation of Rome under Constantine implies that it experienced a significant era of Christian prosperity. This corresponds to the prevailing Christian traditions, monasteries and schools that developed in Nisibis. The significance of the city to Christianity is expressed in the hymns that moaned its surrender to the Persians written by Ephraim (Becker 2006; Russell 2005:179-235).

The religious illustration of the fall of the city at the hands of Julian in 363 CE implies that within Nisibis there was a substantial ecclesiastic-imperial political establishment correspondent to the contemporary dynamics of Christendom. The wars of the emperors against the perspective of an imperial ecclesiastic merger were ultimately the battles of God. Therefore, Christian victory would be divine retribution and the opposite judgement. The didactic implications are to be traced within the conflict between Najran-Himyar and Aksum. In addition, there is arguable room for the deduction of political, economic justification for the actions that were on record as religiously motivated. This would also add to the comprehension of the extent to which the Roman-Byzantine influence determined Aksumite religio-political policy.

\section{Najranite persecutions and the Himyarite war}

Directly connected to the letter of Constantine and its implications on the Persians is the Himyarite-Aksumite conflict. This war is connected to the aforementioned discussion both indirectly and explicitly. The HimyariteAksumite conflict is intrinsically a religious conflict that has geopolitical implications. By extension, the war between Aksum and Himyar also comes to resemble the clash between Rome and Persia in the Red Sea region. The first element to be explored here is the manner in which the conflict between the two nations was derived from a martyrdom account in the same manner as the prolonged war between Rome and Persia was.

There are several sources that relate the accounts pertaining to the conflict; amongst them are hagiographies, such as the Book of the Himyarites and the Martyrium Arethae. The accounts can be evaluated against the Persian persecution and Constantine's precedented response as an arbiter of Christendom. When explored from this angle, the actions of the Aksumite Negus can be weighed against the imperial projection of the patronage of Christianity. In pursuit of the preceding objective discussed, excerpts from the Book of the Himyarites on the martyrdoms of Najran and its correspondent invasion by the Aksumites will be explored. The aim is to deduce the religious nature of the military intervention and the projection of Aksum as a defender and protector of Christianity within its region.

These narratives are relating incidences in the 5th-6th century $\mathrm{CE}$, notably the same timeline in which the martyrdom narratives descriptive of Persian-Roman tensions in Nisibis occurred. Arguably, the martyrdom narratives of Arethas and the Book of the Himyarites would derive principally from the preceding accounts. In addition, there would be some parallel with the ecclesiastical histories such as Theodoret, Sozomen and Eusebius on the Persian war. The portrayals of the ecclesiastic-political establishment as central in the wars are crucial.

\section{Propaganda of a Constantinian narrative}

A section of the Book of the Himyarites details the narrative of freed Najranite confessors and the insignia of the cross on the Himyarites's hands (Book of the Himyarites XLIV. 49a, ed. Moberg 1924:137).

The narratives portray the King Kaleb explicitly as Christian, and there is an emphatic titular reference to the monarch's confession 'believing King Kaleb, Christ loving King Kaleb, God loving King Kaleb' (Book of the Himyarites XLIV.49a, ed. Moberg 1924:137). The manner in which there is a reiteration of the King's religiosity is explicit, and possibly this corresponds to the Constantinian continuum, which depicts the imperial missionary or bishopric role derivative in eulogies such as Eusebius' Life VC and Lanctantius' DMP.

In a correspondent manner, the polemic against the Jews who were the antagonists in this battle is also explicit. In contrast, the retaliatory plunder by the king is painted in a glorious picture, one that is correspondent to how the King had exhorted his armies with a homily derived from the OldTestament's divinely sanctioned military encounters of Israel (Book of the Himyarites XLIII.46a-49a, ed. Moberg 1924:135-137). In a negative assertion, the enemy of Christianity, Masruq, is polemically depicted with titles akin to biblical references to the devil.

The persecutors of Christianity are depicted in a manner that not only justifies the retaliatory actions of Kaleb or Ella Asbeha, but also magnifies them as deliverance. This corresponds significantly to Lactantius' 'Death of the Persecutors'. A brief look at another account implies several insights the Book of the Himyarites XXII relates the 'martyrdom of coronation in the Lord of the freeborn Ruhm, daughter of Azma, and Aumah, her daughter, and Ruhm, hergranddaughter' (Book of the Himyarites XXII.36b-44a, ed. Moberg 1924:126-133). Here is the narrative that also parallels Perpetua's account of martyrdom in its focus on woman martyrs (Farina 2009). As per the source, the death of Ruhm is dated to have been on a Wednesday of the month of Teshri II (Book of the Himyarites XXII.43b, ed. Moberg 1924:133).

Masruq the 'murderer' tormented the handmaids of God, Habsa and Hayya, torturing them by beatings and pulling, after which his lust for blood inclined him to seek out the influential and rich Azma's daughter Ruhm. Azma is also notably related to Harith or Arethas the reputable Christian martyr. The martyr account reads like the 2 nd - 3rd century CE martyrdoms that defined Christian era prior to Constantine 
(Farina 2009). The woman is offered peace and an elevating marriage to a noble man in exchange for her denial of Christianity and acceptance of Judaism, the failure of which to accede would entail death (Book of the Himyarites XXII.36b37a, ed. Moberg 1924:126-127). Ruhm denies the offer of the persecutors vehemently with a homily reflecting Christology, Nicene like anti-Judaic sentiment relating to the deicide (cf. Barnes 2011:124-125; Tertullian On Prayer 14, ed. Schaff 1885a:276-277; VC 3.18.2-4; 19.1, ed. Schaff 1885c:793, 794). Underneath the tone of Ruhm lies a triumphant theme of the persecuted martyrs as victorious and gaining instant entrance into heaven (Book of the Himyarites XXII.37a, ed. Moberg 1924:127). Whilst the reality of persecution has been attested to base on the archaeological and epigraphic evidence (cf. Bowersock 2013; Phillipson 2012), it appears, however, that the narratives are generally edited to reflect an aggregate Christian propaganda, consequent of the political and religious implications of the persecutions of Najran. Christian doctrine intermingled within the martyrs' testimonies; the denunciation of the persecutors added to the military victory of Kaleb and it would seem that this war would be not only physical but also ideological (Baron 1957:3:63-69, 257-260; St Gregentius The Dialogue with Herbanus, ed. Berger 2012: 124-126; Shahid 1976:149). This is arguable based on the practice by Eusebius and Lactantius, amongst others, who had to write a Christian history for Rome.
The polemic is reiterated against the persecutor Masruq as he is entitled the wicked, unclean, murderer, impious and shedder of innocent blood (Book of the Himyarites XXII.39b, 40b, 43a, 44a, ed. Moberg 1924:129-130). Contrary to the derogatory titles of Masruq, Ruhm in Christ-like fashion consoles those crying for her, rather welcoming the persecution (Book of the Himyarites XXII.38b, ed. Moberg 1924:128). There are many biblical parallels to Lukan-Acts accounts Ruhm is said to have done charitable deeds, hence the wailing of the women who had been beneficiaries, like the story of Tabitha, also Ruhm's testimony resembles the sermon of Steven the first Christian martyr Acts 7. She is said to be 'sealed with the sign of the victorious Cross (Book of the Himyarites XXII 38a, ed. Moberg 1924:128)', and this reference to the cross [masqal] and parallel reiterative assertions makes it a theme.

Ruhm had been sealed and had also performed the same for her daughter Aumah and granddaughter with the 'victorious Cross' (Book of the Himyarites XXII 38a, ed. Moberg 1924:128). This was affirmed with the words 'Our Lord Jesus Christ, God of all, save us and the dwellers in this house and all who fear Thy name in every place from denying Thee' (Book of the Himyarites XXII 38a, ed. Moberg 1924:128). The reference to the cross as the object of victory recurs within the text. In XLII.45a-XLV, the cross as a subject is explicit (ed. Moberg 1924:134-139).

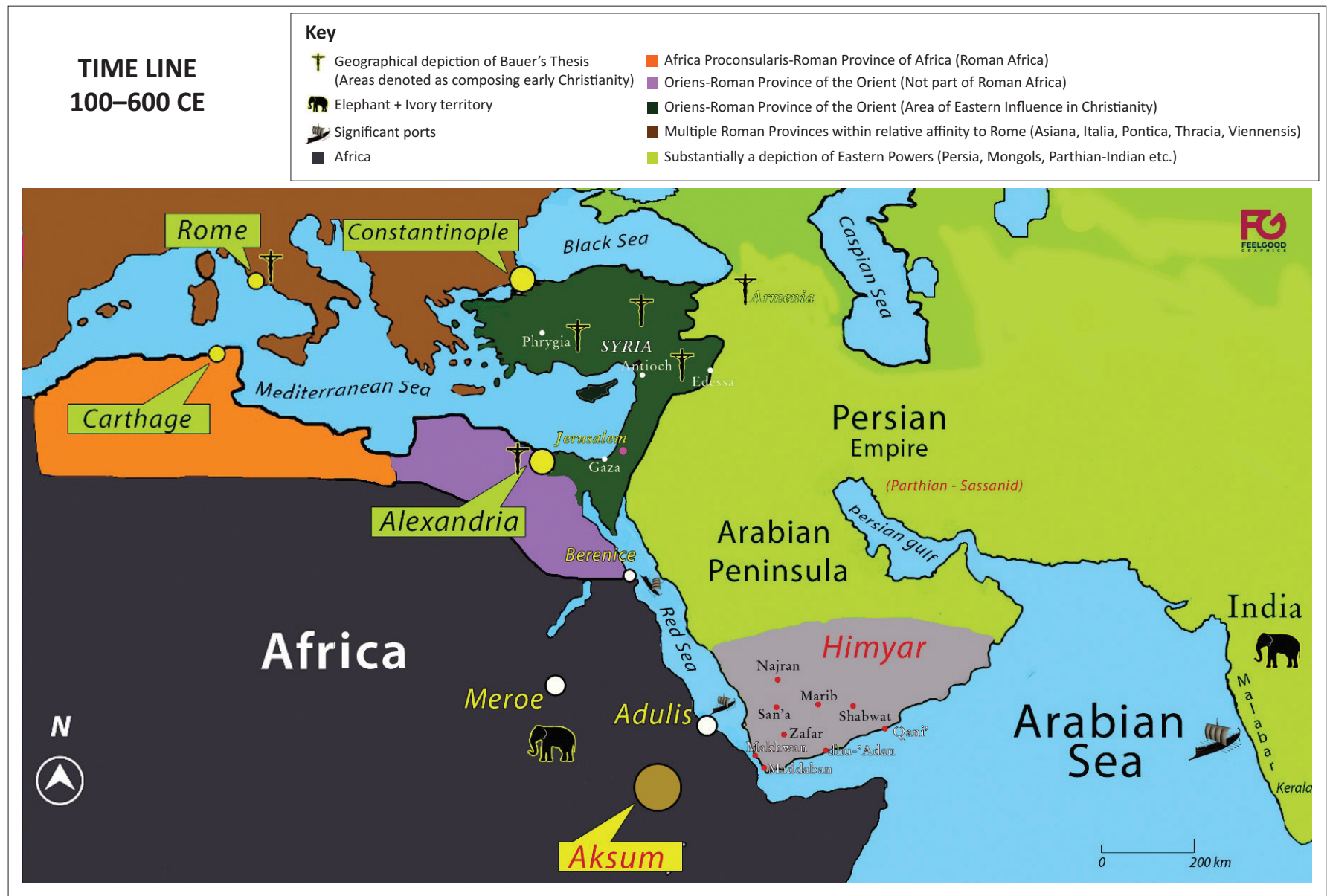

FIGURE 1: Aksum and the world 100-600 CE. 
In XLII.45a-46a, the Himyarites under Masruq are described as fighting the Lord's Cross, and Masruq is entitled the crucifier (ed. Moberg 1924:134-135). This passage recounts the demise of Masruq, who was beheaded by an Ethiopian in the same manner as Goliath. The manner in which the acts of war are immersed in biblical ideology is vivid, Masruq is said to have despised the Ethiopians and extendedly despised the Lord's Cross. Following in XLIII is an extensive homily that recounts the death of the enemies of God's people, an Old Testament theme associated with the battles of Israel. This homily was deductively given by Kaleb himself as correspondent with the opening of the succeeding chapter from the homily XLIV, where the first statement reads as follows:

But after that the believing King Kaleb had spoken, and exhorted his troops with words like these ... (XLIV.49a, ed. Moberg 1924:137)

The homily by the king implies the concept of divine selection in its mentioning of Enoch and Noah a second Adam. A chronology of God's plan typified in his encounter with Abraham and Isaac, Moses with the Israelites in the wilderness, the destruction of nations before Joshua and Gideon's victory. Afterwards, there is a reference to parallels between confrontations of the biblical saints with their enemies with the Church's conflict with Satan (47b-48a). The homily refers back to the immediate war where the King emphasises the victory being a divine sanction. Emphatically, the victory was of the Lord and 'His Cross' not of the army's weaponry but 'His Cross' (48b, ed. Moberg 1924:137).

\section{The victorious cross and the heroic Kaleb}

The story takes a twist where Himyarite Christians who were not able to communicate their Christian confession to the invading Ethiopians because of language tattooed the insignia of the cross on their hands (49b, ed. Moberg 1924:138). Kaleb marvelled at this act of faith in the 'victorious cross'. The king who had ordered all Jews and those who had denied Christianity for Judaism to be killed now put a new law that granted reprieve to anyone who had the cross inscription. As the king decided, this was a sign of conversion. However, there is mention of a petition of repentance being added as well after the realisation that some Jews had tattooed the cross.

In reflection of the passages, the reiteration of the cross theme, it appears that this consolidates with the inscription that refers to the victory through the (masqal) cross. This may be deduced as intrinsically derived from

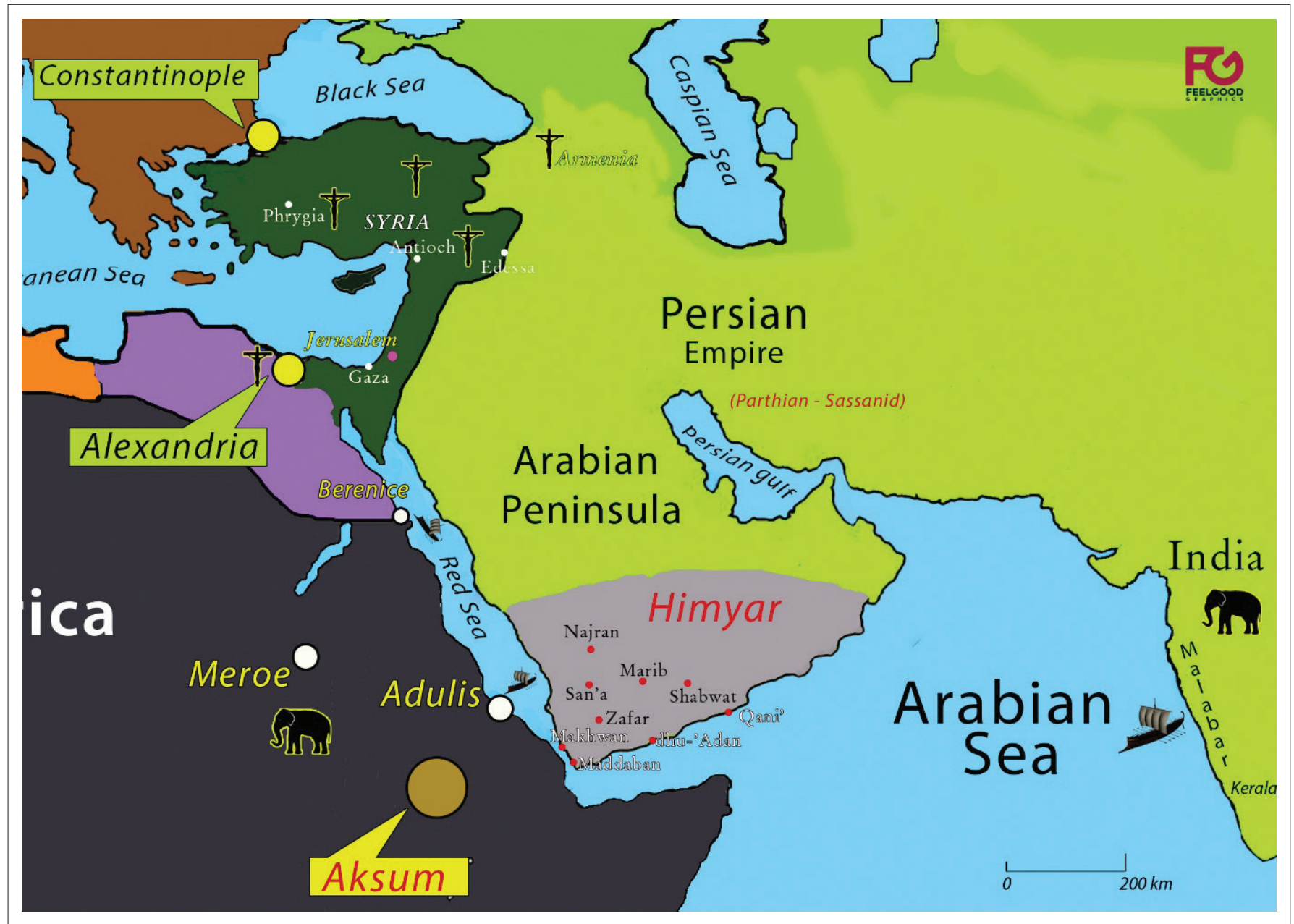

FIGURE 2: The Battle of over Najran and its geographical context. 
Constantine's Milvian bridge and Chrysopolis encounter (cf. Potter 2013:137-146, 207-211). Retrospectively, after the en hoc signi vinces [conquer by this sign] encounter and subsequent victory against Maxentius, the trajectory of Constantine towards a Christianitas Romanitas [Roman Christian statecraft] was entrenched. Eusebius' life and Lactantius' Death of the persecutors affirm this theory. In the battle against Licinius, a persecutor of Christians, Constantine had a banner that illustrated the trinity and it supposedly stroke fear in his enemies.

The use of the cross labarum or rather Chi-Rho sign on the Roman shields, standards and statues furthered the religious aspect of the wars of Constantine (HE 9.9.10-11, ed. Schaff 1885c:584; VC I.28-31, ed. Schaff 1885c:740-742). Therefore, the enemies of Christianity and enemies of the emperor became ultimately the enemies of the cross and enemies of God. This resonates with the manner in which Kaleb viewed his opponent Masruq as the crucifier of Christ. As a result, the identity of the victorious cross had religious as well as political implications as evident in its usage on coinage and inscriptions (Phillipson 2012:189). The language referring to the cross makes the book of the Himyarites sound as a medieval account that is describing a crusade (Tyerman 2006:70). Parallel to this is the reference of the cross on the foreheads of the Christians and the insignia of the cross on their hands is the continuation of the practice amongst Ethiopians. The practice gained a new meaning with the rise of Islam. The cross transcended into an object of spiritual protection. The cross is replete in Ethiopian Iconography and within the Kebra Naghast, it is associated with the protection of rulers (Budge 2000:38, 79,139-140). The reference to a petition of repentance connects the narrative to the martyrdom dynamics of Carthage where there was reference to libelli, certificates of pardon and the categorisation of confessores (Tilley 2006).

Another notable feature is the portrayal of Kaleb or Ella Asbeha as intricately connected to the ecclesiastical establishment. This corresponds to his life narrative, which concludes with him reclining into ascetism, befitting his beatification as a saint (Esteve \& Flores 2006:183). In the Book of the Himyarites, Kaleb is the one to instruct the clergy to pardon the Christians who had apostatised (XLVI.53b, ed. Moberg 1924:140). Kaleb also facilitates the baptism of the new client king he installed in Himyar, the king enforces the words of Euprepios (Book of the Himyarites 54b; 55b, ed. Moberg 1924:140-141). Kaleb also builds churches in Himyar. Aggregately, Kaleb is as attached to the ecclesiastical establishment just as Constantine was.

The Aksumite-Himyarite war has been decoded in various, though appropriate, notions. The usual deduction has been to position the war amidst the dynamics of Roman trade interests in the Red Sea and Aksumite role as an aggregate economic proxy. This is premised as already established on the significance of Adulis, along the Indian route stretching from Berenike to the ancient port of Muziris. This has been thematic in archaeological and historical discussions (Dignas \& Winter 2007; eds. Peacock \& Blue 2007; Sidebotham 2002).

Alternatively, the other method is to attach intrinsic significance to the connection between the HimyariteAksumite conflict and the Byzantine-Persian war and deduce the two nations in conflict as mere proxies (Lee 2006:113-133). The preceding approach bears significance in perspective of the Byzantine-Aksumite Christian alliance that was non-explicit but implied based on the geopolitical policy of Rome. Retrospectively, it should be noted that the Christianisation of Aksum was intrinsically a cultural decision and not a derivative of exotic politics (cf. Haas 2008). The political attachment to the dynamic adoption of Christianity by Aksum is credible primarily when reviewed against the in-attainable balance between the two empires: Persian and Byzantine (cf. Smith 2016). This is because the Byzantine establishment was the one in pursuit of allies and not necessarily the other way around in the case of Aksum. The preceding observation does not negate the reality of Aksumite-Roman relationship prior to the war; however, there is an arguable case for the theory that deduces the overtures of Byzantine as the basis for the Byzantine-Aksumite alliance.

\section{Conclusion}

The above discussion entails the need for a perspective on the Aksumite-Himyarite war that gives adequate regard to the internal and regional aspects of the conflict. It is the arguable case of the research that the persecution of Najran and the ensuing conflict between Himyar and Aksum are symbiotically determined. Whilst the persecutions of Najran have seemingly been connected to the Aksumite-Himyarite conflict, at times it appears that this has been only by extension and reference to the persecution as an appendage to the narrative. Perceivably, a reference to the persecution of Najran as key in decoding the military assaults of King Kalebor Ella Asbeha has the capacity for corroborating a revisionist account. Given the significant parallels that would stem between Kaleb and Constantine's Persian encounter, a substantial case can be developed for the deduction regarding the imperial-ecclesiastical establishment of Ethiopia in the 6th-7th centuries CE. As discussed earlier how the letter of Constantine to Shapur II precipitated events in the looming Byzantine-Persian war, this can be compared to the Himyarite-Aksumite war. This is justifiable as it can be related that in both scenarios, the persecution of Christians acted as an escalating catalyst to the hostilities. As a result, in this case, the persecution will be used as the defining feature of the Aksumite-Himyarite war. In addition, whilst connecting the persecution of Christianity to the AksumiteHimyarite war, it is implied that the war should be decoded mainly as religious.

Eminent author Bowersock (2013) corroborated a narrative that blends the diverse intricacies, relating to AksumiteHimyarite conflict. Bowersock positions the conflict within 
the economic, political and religious dynamics surrounding it. In the title of his book, The Throne of Adulis: Red Sea Wars on the Eve of Isalm, Bowersock decodes the Himyarite-Aksumite war as, composite to the Red Sea trade war between Persia and Rome, and religious war between Christendom and other religions, the result of an expanding Aksumite civilisation that has undergone Christianity and ultimately as the background to the rise of Islam (cf. Bowersock 2013:120).

Central to the title is the geopolitical consciousness of the Aksumite dynasty that perceives itself as descendent from Israelite military history and is in pursuit of a Christian martial-political agenda. The very name of the Negus Kaleb or Ella Asbeha illustrates the preceding claims. Whilst the name Kaleb is the Christian name correspondent to the homilies recorded in the Book of the Himyarites, it is apparent that the Negus or at least his scribes saw Israelite-Judaic wars as derivative for a Christian martial cause. The Old Testament Kaleb was a military man, an accomplice of Joshua, the successor to the Jewish-Egyptian general-prince cum prophet Moses (Dt 32:12). Joshua received divine martial instructions in conflict with Jericho from the Heavenly commander himself (Jos 5). The same Joshua made calls for devotion to Israel, recalling the significance of Torah amongst them (Dt 34:9). As for his Ethiopic name Ella Asbeha [Father of the House of David], there are two implications: Davidic or Solomonic descent and emphasis upon the military, political and religious eminence of the Davidic dynasty (RIE vol. 1. No. 195, stone II.I.24 1991-2000:287).

When placed against this perspective, Kaleb and the Himyarite war build up a narrative of piety and power, the very theme of Constantinian dynamics. Therefore, the persecutions of Najran and the religious themes become inevitably significant to the deduction regarding the Himyarite-Aksumite war. The preceding observation aligns extendedly to the recognition of the place of the war in the rise of prophet Mohammed and correspondingly Islam. The conflict and the succeeding battles that imply the rise of Persian influence on the Arabian Peninsula affirmatively form the construct to the beginning of Islam (Howard-Johnston 2010:397). This is premised on the significance of Himyar upon the Arabian Peninsula (HowardJohnston 2010:415).

Against such a perspective, the rise of Islam as taught by the Quran becomes the development of a new religious ideology within the region of Aksum, against a confluence of competing religious influences such as Judaism, Zoroastrianism, Monophysite-Miasphyte Christianity and semitic paganism (Howard-Johnston 2010:356).

\section{Acknowledgements Competing interests}

The author declares that no competing interest exists.

\section{Author's contributions}

I declare that I am the sole author of this research article.

\section{Ethical consideration}

This article followed all ethical standards for carrying out a research without direct contact with human or animal subjects.

\section{Funding information}

This research received no specific grant from any funding agency in the public, commercial or not-for-profit sectors.

\section{Data availability statement}

Data sharing is not applicable to this article as no new data were created or analysed in this study.

\section{Disclaimer}

The views and opinions expressed in this article are those of the author and do not necessarily reflect the official policy or position of any affiliated agency of the author

\section{References}

Baron, S.W., 1957, A social and religious history of the Jews, Columbia University, New York, NY.

Barnes, T.D., 1985, 'Constantine and the Christians of Persia', Journal of Roman Studies 75(1), 126-136. https://doi.org/10.2307/300656

Barnes, T.D., 1993, Athanasius and Constantius. Theology and politics in the Constantinian Empire, Harvard University Press, Cambridge.

Barnes, T.D., 2011, Constantine. Dynasty, religion and power in the late Roman Empire, Wiley-Blackwell, Chichester.

Becker, A.H., 2006, Fear of god and the beginning of wisdom: The school of Nisibis and Christian Scholastic culture in late antique Mesopotamia, University of Pennsylvania Press, Philadelphia, PA.

Becker, A.H., 2014, 'Political theology and religious diversity in the Sasanian Empire', in G. Herman (ed.) Jews, Christians and Zoroastrians: Religious dynamics in a Sasanian context, pp 7-25, Piscataway, $\mathrm{N}$.

Behr, J., 2004, The Nicene Faith: Formation of Christian theology, vol. 2, St Vladimir's Seminary Press, Crestwood.

Berger, A. (ed.), 2012, 'Life and works of Saint Gregentios, Archbishop of Taphar: Introduction, critical edition and translation', in Millennium-Studien/millennium studies, vol. 7, Walter de Gruyter, Berlin.

Blockley, R.C., 1992, East Roman foreign policy: Formation and conduct from Diocletian to Anastasius, Francis Cairns, Leeds.

Bowen, G.A., 2009, 'Document analysis as a qualitative research method', Qualitative Research Journal 9(2), 27-40. https://doi.org/10.3316/QRJ0902027

Bowersock, G.W., 2013, The throne of Adulis: Red Sea Wars on the Eve of Islam, Oxford University Press, New York, NY.

Brock, S.P., 1982, 'Christians in the Sasanian empire: A case of divided loyalties', in S. Mews (ed.), Religion and national identity, pp. 1-19, Cambridge University Press, Cambridge.

Brock, S.P., 1992, 'Eusebius and Syriac Christianity', in H.W. Attridge \& G. Hata (eds.), Eusebius, Christianity, and Judaism, pp. 212-234, Wayne State University Press, Detroit, MI.

Brock, S.P., 2009, The history of the Holy Mar Ma' in with a guide to the Persian Martyr Acts, Persian Martyr Acts in Syriac: Text and Translation, Fasc. 1, Gorgias, Piscataway, NJ.

Budge, E.W., 2000, The Queen of Sheba and Her Only Son Menyelek: Kebra Nagast, Ethiopian Series Cambridge Publications, Ontario.

Burgess, R.W., 2008, 'The summer of blood: The 'Great Massacre' of 337 and the promotion of the sons of Constantine', Dumbarton Oaks Papers 62, 5-51.

Cameron, A. \& Hall, S.G., 1999, 'Eusebius: Life of Constantine l', in B. Bosworth, M. Grin D. Whitehead \& S. Treggiari (eds.), Clarendon ancient history series, University Press, New York, NY.

Christides, V., 1972, 'The Himyarite-Ethiopian war and the Ethiopian occupation of South Arabia in the acts of Gregentius (ca. 530 A.D.)', Annales d'Ethiopie 9, Année, 115-146. https://doi.org/10.3406/ethio.1972.896

Classen, P., 1977, Kaiserreskript und Königsurkunde, KBE, Thessaloniki.

Corcoran, S., 2006, 'Emperor and citizen in the era of Constantine', in E. Hartley, J. Hawkes \& M. Henig (eds.), Constantine the Great: York's Roman Emperor, pp. 41-51, Lund Humphries, York. 
Cureton, W., 1864, 'The Martyrdom of Habib the Deacon', in Ancient Syriac documents, Oriental Press, Amsterdam.

Danto, E.A., 2008, Historical research, Oxford Scholarship Online, viewed 12 January 2018, from http://www.oxfordscholarship.com/view/10.1093/acprof:0so/9780195 333060.001.0001/acprof-9780195333060.

Debie, M., 2006, 'L'Heritage de la chronique d'Eusebe dans I'historiographie syriaque', Journal of the Canadian Society for Syriac Studies 6, 18-26, Gorgias Press, Piscataway, NJ.

Dewing, H.B. (ed. \& transl.), 1914-1928, Procopius: History of the wars, Heinemann (Loeb Classical Library), London. E-text version, J.I. Jayam, Project Gutenberg Online, viewed 25 March 2019, from http://www.pgdp.net/.

Dignas, B. \& Winter, E., 2007, Rome and Persia in late antiquity, Cambridge University Press, Cambridge.

Dodgeon, M.H. \& Lieu, S.N.C., 1991, The Roman Eastern Frontier and the Persian Wars, AD 226-363: A documentary history, Routledge, London.

Drake, H.A., 2000, Constantine and the Bishops: The politics of intolerance, Johns Hopkins University Press, Baltimore, MD.

Elton, H., 1996, Frontiers of the Roman Empire, Indiana University Press, Bloomington, IN.

Esteve, F.J.G. \& Flores, D.C., 2006, Touching Ethiopia, Shama Books, Addis Ababa.

Farina, W., 2009, Perpetua of Carthage: Portrait of a third-century Martyr, McFarland, Jefferson, MI.

Fear, A.T. (ed. \& transl.), 2010, Seven books of history against the Pagans, Liverpoo University Press, Liverpool.

Frendo, D., 2001, 'Constantine's letter to Shapur II: Its authenticity, occasion, and attendant circumstances', Bulletin of the Asia Institute 15, 57-69.

Ferguson, T.C., 2005, 'The past is prologue: The revolution of Nicene Historiography', in J. Den Boeft, J. Van Oort, W.L. Petersen, D.T. Runia, C. Scolten \& J.C.M. Van Winden (eds.), Supplements to Vigilae Christianae (Formely Philosophia Patrum) texts and studies of Early Christian life and language, Brill, Leiden.

Haas, C., 2008, 'Mountain Constantines: The Christianization of Aksum and Iberia', Journal of Late Antiquity 1(1), 101-126. https://doi.org/10.1353/jla.0.0010

Hendrickx, B., 1984, Official documents written in Greek illustrating the ancient history of Nubia and Ethiopia, Monumenta Afro-Hellenica I, pp. 61-74, IAHS, Johannesburg.

Hendrickx, B., 2012a, 'Political theory and ideology in the KebraNagast: Old Testamen Judaism, Roman-Byzantine Politics and Ethiopian Orthodoxy', Journal of Early Christian History 2(2), 22-35. https://doi.org/10.1080/2222582X.2012.11877263

Hendrickx, B., 2012b, 'The Byzantine limitanei in Egypt: The role of black African troops', Ekklesias-tikos Pharos 94 (New Series 23).

Hendrickx, B., 2017, 'Letter of Constantius II to Ezana and Sezana: A note on its purpose, range and impact in an Afro-Byzantine context', Graeco-Arabica 12 545-556.

Herrmann, G., 2000, 'The rock reliefs of Sasanian Iran', in J.E. Curtis (ed.), Mesopotamia and Iran in the Parthian and Sasanian periods: Rejection and revival c. $238 B C-A D$ 642 , pp. 35-45, British Museum Press, London.

Herrmann, G., Mackenzie, D.N. \& Howell, R., 1989, The Sasanian Reliefs at Naqsh-I Rustam: Nagsh-i Rustam 6. The Triumph of Shapur I, Iranische Denkmaler 13 Dietrich Reimer Verlag, Berlin.

Hollerich, M.J., 1989, 'The comparison of Moses and Constantine in Eusebius of Caesarea's life of Constantine', Studia Patristica 19, 80-85.

Howard-Johnston, J., 2010, Witnesses to a World Crisis: Historians and histories of the Middle East in the seventh century, Oxford University Press, Oxford.

Insoll, T., 2004, Archaeology, ritual, religion, Routledge, London.

Karayannopoulos, I., 1972, Alaiographia, Kodikologia, kai Diplomatiki is ta plaisia ton Byzantinologikon erevnon ton eton 1966-1971, viewed 14 November 2019, from http://ejournals.lib.auth.gr/BYZANTINA/article/view/529.

Kobishchanov, Y.M., 1979, Axum, pp. 67-73, transl. L.T. Kapitanoff, The Pennsylvania State University Press, London.

Lee, A.D., 2006, 'The Empire at war', in M. Maas (ed.), The Cambridge Companion to the Age of Justinian, pp. 113-133, Cambridge University Press, New York, NY.

Leithart, P.J., 2010, Defending Constantine: The twilight of an Empire and the Dawn of Christendom, InterVarsity Press, Downers Grove, IL.

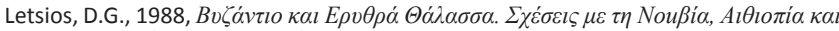

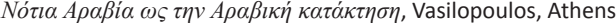

Lieu, J., 2006, 'Self-definition vis-à-vis the Jewish matrix', in M.M. Mitchell \& F.M. Young (eds.), The Cambridge history of Christianity: Origins to Constantine pp. 214-230, Cambridge University Press, New York, NY.

Lincoln, B., 2007, Religion, empire, and torture: The case of Achaemenian Persia, with a Postscript on Abu Ghraib, University of Chicago Press, Chicago, IL.

Lincoln, B., 2008, 'The role of religion in Achaemenian Imperialism', in N. Brisch (ed.), Religion and power: Divine kingship in the ancient world and beyond, pp. 221-41, University of Chicago Press, Chicago, IL.

Mathew, G., 1963, 'The East African Coast until the coming of the Portuguese', in R. Oliver \& G. Mathew (ed.), History of East Africa, vol. 1, Oxford.

Matthews, J.F., 1986, 'Ammianus and the Eastern Frontier in the Fourth Century: A participant's view', in P. Freeman \& D. Kennedy (ed.), The defence of the Roman and Byzantine East, pp. 549-564, BAR International Editions, Oxford.

Millar, F., 1982, 'Emperors, frontiers and foreign relations, 31 B.C. to A.D. 378', Britannia 13, 1-25.
Mingana, A., 1907, Sources Syriaqes, vol. 1, Harrasowitz, Leipzig.

Moberg, A. (ed. \& transl.), 1924, The book of the Himyarites, Lund: Acta regiae Societatis humaniorum litterarum Lundensis 7 , London.

Munro-Hay, S., 1991, Aksum - An African civilisation of late antiquity, ch. 4, p. 6 Edinburgh University Press, viewed 10 Novemebr 2019, from https://www. Britishmuseum.org/.../KingdomOfAksum.

Pankhurst, S., 1956, Ethiopia. A cultural history, Lund, London.

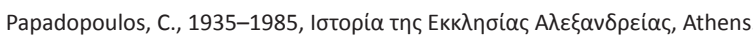

Peacock, D. \& Blue, L. (eds.), 2007, The ancient Red Sea port of Adulis, Eritrea. Report of the Eritro-British Expedition, 2004-5, Oxbow, Oxford.

Phillipson, D.W., 2012, Foundations of an African Civilisation: Aksum \& the Northern Horn 1000 BC-AD 1300, James Currey, New York, NY.

Potter, D., 2013, Constantine the emperor, Oxford University Press, Oxford.

Rapp, C., 1998, 'Imperial ideology in the making: Eusebius of Caesarea on Constantine as "Bishop"', Journal of Theological Studies 49, 685-695, Oxford University Press, Oxford.

Ridley, R.T., 1982, Zosimus new history: A translation with commentary, Byzantina Australiensia 2, Australian Association for Byzantine Studies, Department of Greek, University of Sydney, Sydney.

RIE I-III., Bernand, E., Drewes, A.J. \& Schneider, R., 1991-2000, Recueil des Inscriptions de l'Ethiopie des periodes preaxoumite et axoumite, introduction by Fr. Anfray, $3 \mathrm{vols}$, vol 1, Les documents, vol. 2, Lesplanches, vol. 3, Traductions et commentaires $A$. Les inscriptions grecques par E. Bernand, Paris.

Ritchie, J. \& Lewis, J., 2003, Qualitative research practice: A guide for social science students and researchers, Sage, London.

Roldanus, J., 2006, The Church in the age of Constantine: The theological challenges, Routledge, London.

Rukuni, R., 2018, The Schism, Hellenism and politics: A review of the emergence of Ecumenical Orthodoxy AD 100-400, University of South Africa, Pretoria.

Russell, P.S., 2005, 'Nisibis as the background to the life of Ephrem the Syrian', Hugoye 8, 179-235. https://doi.org/10.31826/9781463214142-012

Schaff, P. (ed.), 1885a, Ante-Nicene fathers, vol. 3: Latin Christianity: Its Founder, Tertullian, Christian Classics Ethereal Library, Grand Rapids, MI.

Schaff, P. (ed.), 1885b, Nicene and post-Nicene fathers, ser. 2, vol. 1: Eusebius Pamphilius: Church History, Life of Constantine, Oration in Praise of Constantine, Christian Classics Ethereal Library, Grand Rapids, MI.

Schaff, P. (ed.), 1885c, Nicene and post-Nicene fathers, ser. 2, vol. 2: Socrates and Sozomenus Ecclesiastical Histories, Christian Classics Ethereal Library, Grand Rapids, MI.

Schaff, P. (ed.), 1892, Nicene and post Nicene fathers, ser. 2, vol. 4: Athanasius: Select Works and Letters: Ecclesiastical History, Christian Classics Ethereal Library, Grand Rapids, MI.

Scher, A., 1908, Histoire nestorienne inedite (Chronique de Seert), PO 4, Firmin-Didot, Paris.

Sellassie, S.H., 1966, 'Church and State in the Ak-sumite Period', in Proceedings of the 3rd International conference of the Ethiopian Studies, Institute of Ethiopian Studies, Haile Selassie I University, Addis Ababa.

Sellassie, S.H., 1971, 'Die Aethiopische Kirche im 4 bis 6 Jahrhundert', Abba Salama II, 43-75.

Sellassie, S.H., 1972, Ancient and Medieval Ethiopian history to 1270, Addis Ababa.

Seston, W., 1947, 'Constantine as a "Bishop"', Journal of Roman Studies 37, 127-131, Cambridge University Press, Cambridge.

Shahid, I., 1976, 'The Kebra Naghast in the light of recent research', Le Museon 89 (1976), 133-178

Shahid, I, 1976, 'The Kebra Naghast in the light of recent research', Le Museon 89(1976), 133-178, republished in A. Bausi (ed.), 2012, Languages and cultures of Eastern Christianity: Ethiopian, Ashgate Publishing Ltd, Surrey, pp. 253-298.

Sidebotham, S.E., 2002, 'Late Roman Berenike', Journal of the American Research Center in Egypt 39(1), 217-240. https://doi.org/10.2307/40001157

Smith, K., 2014, The Martyrdom and history of blessed Simeon bar S. abba 'e, Persian Martyr Acts in Syriac: Text and Translation, Fasc. 3, Gorgias, Piscataway, NJ.

Smith, K., 2016, Constantine and the captive Christians of Persia: Martyrdom and religious identity in late antiquity, University of California Press, California, CA.

Tilley, M.A., 2006, 'North Africa', in M.M. Mitchell \& F.M. Young (eds.), The Cambridge history of Christianity: Origins to Constantine, pp. 485-503, Cambridge University Press, New York, NY.

Turtledove, H., 1982, The chronicle of Theophanes, University of Pennsylvania Press, Philadelphia, PA.

Tyerman, C., 2006, God's war: A new history of the Crusades, Penguin Group, London. Ullendorff, E., 1956, 'Hebraic-Jewish elements in Abyssinian (Monophysite) Christianity', Journal of Semitic Studies 1(Fasc. 3), 216-256. https://doi.org/10.1093/jss/1.3.216

Ullendorff, E., 1956, 'Hebraic-Jewish elements in Abyssinian (Monophysite) Christianity', Journal of Semitic Studies 1, 216-256, republished in A. Bausi (ed.) 2012, Languages and cultures of Eastern Christianity: Ethiopian, Ashgate Publishing Ltd, Surrey, pp. 122-161.

Van Dam, R., 2011, Remembering Constantine at the Milvian Bridge, Cambridge University Press, New York, NY. 
Vasiliev, A.A., 1950, Justin the first, Harvard.

Warmington, E.H., 1974, The commerce between the Roman Empire and India, 2nd edn., Curzon and Octagon, New York, NY.

Warmington, H., 1981, 'Ammianus Marcellinus and the lies of Metrodorus', Classical Quarterly 31(2), 464-468, viewed 17 May 2019, from https://doi.org/10.1017/ S0009838800009794

Whelan, R., 2018, Being Christian in Vandal Africa: The politics of orthodoxy in the Post-Imperial West, University of California Press, Oakland, CA.
Wright, W., 1871, Catalogue of Syriac manuscripts in the British Museum, acquired since the year 1838, vol. 2, pp. 631-633, British Museum, London.

Wright, W. \& McLean, N., 1898, The ecclesiastical history of Eusebius in Syriac, Cambridge University Press, Cambridge.

Yamauchi, E.M., 1972, The stones and the scriptures, Holman, New York, NY.

Yonge, C.D. (transl.), 1911, The Roman History of Ammianus Marcellinus: During the Reigns of the Emperors Constantius, Julian, Jovianus, Valentinian, and Valens, Bell \& Sons, London, viewed 25 October 2019, from http://www.pgdp.net. 